\title{
Oral communication and auditory skills of hearing impaired children and adolescents and the speech therapy rehabilitation process
}

\author{
Habilidades auditivas e de comunicação oral de crianças \\ e adolescentes deficientes auditivos e o processo \\ de reabilitação fonoaudiológica
}

Rafaela da Silva Bicas(1)

Laura Mochiatti Guijo(1)

Eliane Maria Carrit Delgado-Pinheiro(1)

\begin{abstract}
(1) Universidade Estadual Paulista Júlio de Mesquita Filho - Faculdade de Filosofia e Ciências, UNESP, Marília, São Paulo, Brasil.
\end{abstract}

Conflict of interest: non-existent

Received on: 11/21/2016

Accepted on: 07/12/2017

Mailing address:

Rafaela Cristina da Silva Bicas

Rua Francisco Franco do Nascimento,

$n^{0} 220$, casa 51 ,

Sítios de Recreio Nascimento

Marilia, São Paulo, Brasil

CEP: $17514-061$

E-mail - rafaelabicas@gmail.com

\section{ABSTRACT}

Purpose: to analyze auditory and oral communication behaviors in a group of children and adolescents, users of cochlear implants and to establish a relationship with factors that interfere with aural rehabilitation. Methods: participants were 13 children or adolescents with profound bilateral sensorineural hearing loss. Standardized procedures were applied to check: the auditory and oral communication behaviors of participants and their relationships with the child's age at diagnosis period; the interval between diagnosis and intervention, adaptation onset of the cochlear implant; the hearing age and aural rehabilitation period.

Results: statistically significant data were found to correlate the interval between diagnosis and intervention with the scores in the evaluation procedures of oral communication.

Conclusion: there was a significant impact on the development of oral communication when the period elapsed between the diagnosis and intervention was analyzed, in such way that the faster the intervention time, the better the results. It was also evident that the earlier the beginning of the use of cochlear implants, the greater the hearing age, and the longer the rehabilitation period, the better the scores in the procedures that evaluated auditory and verbal development.

Keywords: Hearing Loss; Cochlear Implant; Language; Auditory Perception

\section{RESUMO}

Objetivo: analisar os comportamentos auditivos e de comunicação oral em um grupo de crianças e adolescentes usuários de implante coclear e estabelecer relações com fatores que interferem na reabilitação auditiva.

Métodos: participaram deste estudo 13 crianças ou adolescentes com deficiência auditiva sensorioneural profunda bilateral. Foram aplicados procedimentos padronizados para verificar: 0 comportamento auditivo e de comunicação oral dos participantes e estabelecidas relações com a idade da criança no período do diagnóstico; 0 intervalo entre o diagnóstico e a intervenção, época de ativação do implante coclear; a idade auditiva e o período de reabilitação auditiva.

Resultados: foram encontrados dados estatisticamente significantes ao correlacionar o intervalo entre 0 diagnóstico e a intervenção com os escores dos procedimentos de avaliação da comunicação oral.

Conclusão: houve impacto significante no desenvolvimento da comunicação oral quando analisado 0 período transcorrido entre 0 diagnóstico e a intervenção, de tal forma que quanto mais rápida a intervenção, melhores os resultados. Foi evidente também que quanto mais precoce o início da utilização do implante coclear, maior idade auditiva e maior o período de reabilitação, melhores foram os escores nos procedimentos que avaliaram desenvolvimento auditivo e verbal.

Descritores: Perda Auditiva; Implante Coclear; Linguagem; Percepção Auditiva 


\section{INTRODUCTION}

Profound sensorineural hearing loss for many years has been a limitation for the auditory and communicative development in prelingual deaf children, due to insufficient stimulus to promote the development of spoken language ${ }^{1,2}$. Early stimulation of peripheral and central auditory pathways exerts an important impact on the development of auditory and oral communication skills. Thus, the detection and early intervention of sensorineural hearing loss have become fundamental aspects for a good prognosis in aural rehabilitation.

Over the years in Brazil, there have been public health ordinances developed that directly benefited the population of hearing impaired children. Some examples are the Ordinance GM/MS No. 1278, on October 20, 1999, which established criteria for indication and contraindication of Cochlear Implant $(\mathrm{Cl})^{3}$, Decree No. 7612 on November 17, 2011, which established the National Plan for the Rights of the Disabled - Live Without Limits Plan ${ }^{4}$, and the Ordinance No. 21/SCTIE/MS on May 7, 2013, which made public the decision to incorporate Personal Frequency Modulation (FM) System which allows hearing impaired children and/or young person access to Brazil's Unified Health System (SUS - Sistema Único de Saúde) ${ }^{5}$, and more recently, the Ordinance GM/MS No. 2776 on December 18, 2014, which approves, extends and incorporates procedures for Specialized Attention for Hearing Impaired Persons in the Brazilian Unified Health System, where one of these procedures is bilateral cochlear implant surgery ${ }^{6}$.

Technological advances and public policies allow for a transformation in the panorama of the quality of life of these children, as there is the possibility of detection of hearing loss and early intervention ${ }^{7-11}$. The early forwarding of hearing impaired children to a language therapy intervention program becomes a preventative action against the secondary alterations of hearing impairment ${ }^{12-15}$. However, studies have shown that in developing countries there is a relatively extensive period between diagnosis and intervention when compared to the ideal period for the development of auditory and oral skills ${ }^{15}$.

Literature highlights the importance of early diagnosis and intervention due to the great impact that may result in the early years of life, considering that this is the period of greater plasticity of the central nervous system $^{10,16}$. Still at this stage of life, the child uses his hearing for the initial contact with the oral sounds, thus the phono-articulatory proprioception provides the development of feedback-auditory, preparatory for the improvement of one's own speech ${ }^{17-19}$.

Moreover, there are other factors presented in literature and experienced in clinical practice as a preponderant for the development of hearing (auditory) and oral communication skills, such as: degree of hearing loss, stability of the degree of this loss, adaptation of the auditory technological resource and aural rehabilitation ${ }^{20-22}$. Studying the relationship of these factors can assist aural rehabilitation programs by providing important information for the formation of behavior with emphasis on oral communication and the development of the hearing function.

Intervention begins with the appropriate adaptation of the electronic device, which will give children the possibility of receiving oral and hearing stimuli ${ }^{23}$ so that together with the initiation of early aural rehabilitation, the development of their communication will occur. There is then the need for the adaptation of the electronic device according to the particularities and the degree of hearing loss. In this context of the aural rehabilitation process, insertion into a language therapy program that promotes the development of auditory abilities and oral communication in an effective manner should also be considered.

Aiming for this objective, the literature highlights the auditory verbal approach, which provides communicative independence to the hearing impaired through spoken language. For this to happen, the audiologist should lead the child and his family, providing this development through the integration between auditory and oral communication skills ${ }^{24,25}$.

In therapeutic sessions, the relationship between the audiologist and the relatives of children and adolescents with hearing impairment enables the therapist to extract important information about the auditory and linguistic development provided by these parents, as well as the frequency in which these skills appear in their everyday life. Different protocols are used for this purpose, such as the Infant-Toddler Meaningful Auditory Integration Scale (IT-MAIS), the Meaningful Auditory Integration Scale (MAIS), and the Oral Language Assessment Questionnaire ${ }^{26-28}$.

It is noted that the time of diagnosis and initiation of intervention, age at the beginning of the use of cochlear implant, the hearing age and participation in the therapeutic process are factors that interfere in aural rehabilitation.

The objective of this study was to analyze the auditory behaviors and oral communication in a group 
of children and adolescents with cochlear implant and establish relationships with factors that interfere in aural rehabilitation.

\section{METHODS}

This research was conducted at the Center for Education and Health Studies (CEHS), São Paulo State University. It was evaluated and approved by the Research Ethics Committee of the institution of origin (case No. 732/2013) and complied with resolution No. $466 / 12$ of the National Health Council and the "free and clarified consent term" was signed by all those responsible for the subjects involved.

This is an observational, descriptive cross-sectional study.

The participants were selected according to the inclusion and exclusion criteria, with 13 children or adolescents included in the sample with bilateral profound sensorineural hearing loss that:

(a) Regularly use unilateral Cochlear Implant (CI), i.e. they use the device every day, throughout the period in which they are awake, taking it out only in activities involving humidity, such as bathing;

(b) Participate or previously participated in a therapeutic speech process emphasizing the development of hearing and oral communication with the use of a Hearing Aid for a minimum period of six months, where none benefited from the use of the hearing aid for the period in which they were used, criterion also used in the indication of $\mathrm{Cl}$;

(c) Family members received guidance regarding the aural rehabilitation process, such as the importance of regular use of the cochlear implant, participation in the therapeutic speech process, strategies that enable the development of hearing and oral communication in the house environment;

\section{Excluded from this study were:}

(a) Deaf children and adolescents who exclusively use the hearing aid;

(b) Children and adolescents with associated neurological alteration;

(c) Children and adolescents with Auditory Neuropathy Spectrum Disorder;

(d) Post-lingual hearing impaired.

All selected participants performed the hearing deficiency diagnosis, as well as other interventions in the Unified Health System. In the public aural rehabilitation program in which the participants were inserted, the social service professionals performed the socio-economic description analyzing family factors, such as housing, transportation, number of people with special needs in the family and income per capita. In relation to income, three households presented income below 0.5 minimum wage per capita, seven families between 0.5 and 1.0 minimum wage per capita and three families between 1.0 and 2.0 minimum wages per capita.

The documentary analysis of the charts allowed the information concerning: age of the child at the time of diagnosis, time interval between diagnosis and rehabilitation, rehabilitation period, age of the child at the beginning of the $\mathrm{Cl}$ use and hearing age.

The following procedures were used for assessing the auditory behavior of the participants:

- Infant-Toddler Meaningful Auditory Integration Scale ${ }^{26}$, which aims to assess the perception of speech sounds in hearing impaired children aged less than four years old. The scale consists of 10 simple questions related to the child's auditory behavior in different everyday situations. Each question can be scored up to five points, with scores from zero to four where zero (0) refers to never, one (1) rarely, two (2) occasionally, three (3) frequently and four (4) always. The questions are presented to the parents in the form of an interview in which the description of the auditory behavior is requested, with examples of each auditory behavior questioned. From the description of the parents and the analysis of the examples reported, the responses are scored according to their occurrence. After the applying the interview, the result is calculated by adding the total number of points accumulated in each question, with a maximum of 40 possible. The score can be transformed into percentage, at which 40 points corresponds to $100 \%$ and a great auditory development in relation to the attention and recognition of speech sounds.

- Meaningful Auditory Integration Scale ${ }^{27}$, to evaluate children older than 4 years old, with the purpose of quantifying the frequency with which the same auditory behaviors already cited occur in the population at this age, applying the questionnaire as previously described, by means of questions to the parents, in the form of an interview.

The following was used in evaluating oral communication behavior:

- Oral Language Assessment Questionnaire ${ }^{28}$ which aims to evaluate the use of oral communication by 
the hearing impaired child, in his day-to-day routine. Originally this procedure presents two versions of questions, one used with children under five years and another above that age group. The questionnaire consists of 10 questions that evaluate the use of voice, use of oral communication with family and the use of oral communication with unfamiliar people. Responses are scored from the reports and examples presented by the parents. The scores vary from zero to four, evaluating from language behavior never observed to frequently present language behavior. The final score corresponds to the sum of the values of the 10 questions, with a maximum value of 40 points which corresponds to $100 \%$.

Semantic adjustments were carried out in the questions that evaluate oral communication and hearing abilities of children aged higher than the proposed procedures, replacing the word "child" contained in the question with "adolescent" and replacing examples of the infant routine with other appropriate examples of the activities of a teenager, maintaining the objective of evaluating the use of the hearing and oral communication function in everyday situations.
The instruments were applied in the form of an interview to parents, recorded, transcribed, scored according to the examples presented in the responses and transformed into percentage. For recordings performed in a therapeutic environment, the Panasonic RR 85450 IC recorder was used.

The data obtained during the survey was correlated and statistically analyzed using the Pearson correlation test, complying with the significance rule: $p<0.05$.

\section{RESULTS}

The results were organized aiming at analyzing the studied information and the results of the auditory behavior and oral communication. Table 1 presents the results obtained as:

- The age at diagnosis

- Length of participation in the rehabilitation process;

- Participant's age at $\mathrm{Cl}$ activation;

- Hearing age;

- Interval between diagnosis and auditory intervention;

- Frequency of auditory behavior;

- Frequency of oral communication behavior.

Table 2, presents the descriptive statistic carried out under the results of Table 1.

Table 1. Results of factors involved in the aural rehabilitation process and auditory and oral communication behaviors

\begin{tabular}{ccccccc}
\hline $\begin{array}{c}\text { Age at diagnosis } \\
\text { (in months) }\end{array}$ & $\begin{array}{c}\text { Period of } \\
\text { auditory } \\
\text { rehabilita-tion } \\
\text { (in months) }\end{array}$ & $\begin{array}{c}\text { Age of child at } \\
\text { initial Cl usage } \\
\text { (in months) }\end{array}$ & $\begin{array}{c}\text { Hearing age (in } \\
\text { months) }\end{array}$ & $\begin{array}{c}\text { Time Interval } \\
\text { between } \\
\text { diagnosis and } \\
\text { interven-tion } \\
\text { (months) }\end{array}$ & $\begin{array}{c}\text { Frequency of } \\
\text { oral communica- } \\
\text { tion behavior } \\
\text { (percentage) }\end{array}$ & $\begin{array}{c}\text { Frequency } \\
\text { of auditory } \\
\text { behavior } \\
\text { (percentage) }\end{array}$ \\
\hline 4 & 20 & 11 & 15 & 7 & 100.00 & 100.00 \\
23 & 31 & 33 & 26 & 10 & 85.00 & 85.00 \\
12 & 11 & 39 & 59 & 27 & 37.50 & 77.50 \\
31 & 32 & 57 & 7 & 26 & 75.00 & 87.50 \\
20 & 103 & 25 & 97 & 5 & 97.50 & 97.50 \\
19 & 98 & 43 & 100 & 24 & 100.00 & 100.00 \\
15 & 94 & 21 & 87 & 6 & 100.00 & 100.00 \\
28 & 75 & 49 & 54 & 21 & 62.50 & 80.00 \\
34 & 84 & 56 & 66 & 22 & 55.00 & 70.00 \\
32 & 176 & 54 & 141 & 22 & 100.00 & 100.00 \\
25 & 49 & 39 & 93 & 14 & 100.00 & 100.00 \\
25 & 103 & 42 & 102 & 17 & 87.50 & 95.00 \\
16 & 88 & 33 & 72 & 17 & 95.00 & 90.00 \\
\hline
\end{tabular}

Legend: $\mathrm{Cl}=$ Cochlear Implant 
Table 2. Descriptive statistic of the factors involved in aural rehabilitation

\begin{tabular}{lccccc}
\hline Variables & Average & SD & Minimum & Median & Maximum \\
\hline IAge at diagnosis (in months) & 21.84615 & 8.668392 & 4 & 23 & 34 \\
Time of aural rehabilitation (in months) & 74.15385 & 45.16792 & 11 & 84 & 176 \\
Age of child at initial Cl usage (in months) & 38.61538 & 13.95552 & 11 & 39 & 57 \\
Period of Cl use (in months) & 70.69231 & 38.5495 & 7 & 72 & 141 \\
Time of interval between diagnosis and intervention (months) & 16.76923 & 7.736858 & 5 & 17 & 27 \\
Frequency of oral communication behavior (percentage) & 84.23077 & 20.70086 & 5 & 95 & 100 \\
\hline
\end{tabular}

Legend: $\mathrm{SD}=$ Standard Deviation; $\mathrm{Cl}=$ Cochlear Implant

The Tables demonstrate that the age of diagnosis of the participants ranged from 4 to 34 months $(=21.84$ months). The child who was diagnosed before one year of age presented results of $37.50 \%$ to $100 \%$ in the analysis of oral communication behaviors and scores of $77.5 \%$ to $100 \%$ in auditory behaviors.

It is noted that the child diagnosed before one-year old and obtained scores of $100 \%$ in the two procedures was the one that also had effective access to speech sounds, with $\mathrm{Cl}$, before completing 12 months of life. In addition, four participants diagnosed before two years of age presented scores more than $85 \%$ in both instruments.

The aural rehabilitation period of the participants of this study varied from 11 to 176 months in a program whose used approach emphasized the development of oral communication and hearing function $(=74.15$ months). Among the participants, one reached the score of $100 \%$ in both procedures with 20 months of participation in the therapeutic hearing process and four other participants reached the same scores with a period ranging from 49 to 176 months. This information demonstrates that the variety of other data permits the aforementioned outcome. It was noted that the child who reached the maximum score with 49 months of participation in the therapeutic process obtained diagnosis and intervention in an early period when compared to that with 176 months of rehabilitation.

The minimum age of the children at the beginning of the $\mathrm{Cl}$ use was 11 months and the maximum of 57 months $=38.61$ ). Five children who were placed within the age range of 3 years, reached scores of $85 \%$ to $100 \%$ in both procedures.

With regard to the hearing age, the results demonstrated variation from 7 to 141 months $(=70.69$ months). It is noted that a child whose hearing age was 15 months reached the maximum score in both procedures, and two other children attained scores near to $100 \%$ with hearing age around two years of age.

Another factor analyzed was the time interval between detection of hearing loss and the onset of therapeutic process. The results demonstrated intervals ranging from 7 to 27 months (=16.76), and seven participants with a range of less than 17 months reached scores near $100 \%$ in both procedures.

Statistical analysis was used with Pearson's Correlation Coefficient to verify the correlation between the data. The results of this analysis demonstrated the significant correlation on the interval between the diagnosis and the speech therapy intervention and the scores obtained in the oral communication scale, presenting the result of 0.033 (Table 3 ). 
Table 3. Results of Pearson correlation coefficient

\begin{tabular}{cc}
\hline Variables & $\begin{array}{c}\text { Statistical correlation/significance level with auditory } \\
\text { behaviour scores }\end{array}$ \\
\hline Age at diagnosis & 0.272 \\
Time of aural rehabilitation & 0.245 \\
Age of child at initial Cl usage & 0.103 \\
Period of Cl use & 0.158 \\
Interval between diagnosis and intervention & 0.094 \\
\hline Variables & Statistical correlation/significance level with Oral \\
Communication Scores
\end{tabular}

It was noted that there was a correlation of 0.094 of the interval values between diagnosis and rehabilitation with the scores obtained in the auditory behavior assessment, which demonstrates the impact of this variable near that which is considered relevant by this survey.

The results demonstrate that among the variables involved in the aural rehabilitation process, the time interval between diagnosis and intervention was what demonstrated significant correlation with the results of oral communication, obtaining the value of significance $p=0.033$, however, it can be observed that this same variable, when correlated to the auditory behavioral scores presented $p=0,094$, in a margin near the value established as that of significance.

The results demonstrated that among the 13 participants, nine presented scores above $85 \%$ and five reached the score of $100 \%$ in both procedures.

It is necessary to highlight that, although there is no significant correlation between the other variables observed, all have a direct impact on the scores obtained, influencing them to a lesser or higher degree, according to the values of $p$ presented.

\section{DISCUSSION}

Studies demonstrate that there are distinct factors capable of influencing the prognosis of hearing and oral communication of children with hearing impairment ${ }^{29,30}$.

Currently, children and adolescents with profound sensorineural hearing loss are able to develop the hearing and speech function through electronic devices such as $\mathrm{Cl}$ and the appropriate involvement of the factors analyzed by this research.

The results of this study demonstrated that the diagnosis age of the participants ranged from 4 to 34 months. Children who were diagnosed before one year of age presented results from $37.50 \%$ to $100 \%$ in the procedure for evaluating oral communication behaviors and from $77.5 \%$ to $100 \%$ in evaluating auditory behaviors. It is noted that the participant who reached the score of $37 \%$ should be analyzed separately, considering other variables, such as the extensive period between diagnosis and intervention ( 27 months), more than three years of age in the adaptation period of the implant and the hearing age of less than one year, factors that have directly influenced in obtaining such score.

These results corroborate the literature demonstrating the impact of diagnosis and insertion in an early rehabilitation program in the development of auditory and spoken language skills ${ }^{10,17,20,31}$.

It is noted that the child diagnosed before a year of age and obtained scores of $100 \%$ in the two procedures was one that also had effective access to speech sounds, with $\mathrm{Cl}$, before completing 12 months of life. Furthermore, the five participants diagnosed before two years of age presented scores more than $85 \%$ in both evaluations.

Similar data were found in the study that concluded that when adapted before 12 months of age, $\mathrm{Cl}$ offers a better and more agile performance in the auditory and speech development when associated with early intervention ${ }^{32}$. 
The results demonstrated that among the 13 participants with profound hearing impairment, nine presented scores above $85 \%$ and five reached the score of $100 \%$ in both procedures. It may be observed, therefore, that profound hearing loss was not a limiting aspect in obtaining the results in hearing and spoken language. These findings corroborate the study which states that the use of the cochlear implant can allow access to speech sounds for profound hearingimpaired children ${ }^{33}$.

The period of participation in the therapeutic speech process whose approach emphasized the development of the auditory and speech function, varied from 11 to 173 months ( $=74.15$ months). Aural rehabilitation inserts the child into oral communication, using the appeal of auditory integration, with the purpose of enabling the child or adolescent to become communicatively independent ${ }^{24,25,34}$.

Among the participants of this study, one achieved the score of $100 \%$ in both procedures at 20 months of therapeutic process and four other participants reached the peak scores with a period ranging from 49 to 176 months. This finding corroborates with the study that demonstrated the fact that multiple factors are interconnected in the final results of communicative abilities ${ }^{22}$.

In relation to the age of children at the beginning of $\mathrm{Cl}$ usage, it is observed that the minimum age was 11 months and the maximum of 57 months ( $=38.61)$. One study concluded that children implanted before three years of age have hearing perception superior to those implanted at a later age ${ }^{35}$. This study produced the same results, as children who were implanted within the age range of 3 years, marking the initiation of auditory perceptions for verbal sounds, reached scores of $85 \%$ to $100 \%$ in both procedures.

The hearing age ranged from 7 to 141 months ( = 70.69 months), highlighting a child whose hearing age was 15 months reached the score of $100 \%$ in both procedures, and two other children reached scores near $100 \%$ with hearing age around two years of age. Studies describe significant results in the evaluation between the hearing age and the scores of hearing and speech skills ${ }^{22}$.

Studies also observed the period of $\mathrm{Cl}$ use in children and their auditory and verbal performance by likening them to the performance of a hearing child at similar age to the period of sound stimulation, finding similar performances by children whose adaptation to the device was achieved early. The authors highlight the relationship between the sensorial deprivation period and the functional hearing period, causing both factors to be related to a better score of auditory and linguistic behavior, corroborating with the fact that children of this study have reached high scores with restricted hearing age $^{36}$.

Another factor analyzed was the time interval between hearing loss detection and initiation of aural rehabilitation. Participants with lesser interval time between diagnosis and initiation of rehabilitation obtained scores above $85 \%$.

In statistical analysis, the results demonstrated the significant correlation on the interval between diagnosis and speech therapy intervention with the scores obtained in the oral communication scale, presenting the result of 0.033 .

There was also correlation of 0.094 of the interval values between diagnosis and rehabilitation with the scores obtained in the auditory behavior assessment, which demonstrates the impact of this aspect in the scores presented by the scales.

These data corroborate the study which concluded that children from developing countries appear for intervention, even after late diagnosis, hindering the development of auditory, cognitive and language skills ${ }^{16}$.

A study was conducted involving the diagnosis before six months of age, with variation in the degree of hearing loss, maintaining the intervention period. Thus, the author encountered high oral communication scores in 92 participants whose loss varied from mild to moderate and 90 participants with the same result, however, with profound hearing loss, obtaining a non-significant difference with regard to the degree of hearing loss ${ }^{10}$.

The same finding may be evidenced in this study, since the average of the scores for oral communication behaviors obtained from the scales was $84.23 \%$ and the average of the auditory behaviors was $90.96 \%$. These data demonstrate the ability of children with profound sensorineural hearing loss to reach scores near $100 \%$, both in auditory behaviors and oral communication.

The results demonstrated that all aspects analyzed in the aural rehabilitation process may interfere in oral and hearing behaviors presented by children or adolescents with pre-lingual sensorineural hearing loss, and should be considered in the therapeutic process.

In statistical analysis, significant correlation of the time interval between diagnosis and intervention with oral communication frequency was presented, obtaining $p=0.033$. The other factors studied would require a larger number of participants to analyze 
statistical significance, however, it is possible to visualize the influence of all factors in the auditory and speech results.

It is important to highlight that this study involved teenagers using the Unified Health System and that they benefited from the unilateral cochlear implant, but did not take advantage of the benefits provided by neonatal hearing screening. Thus, the results of this study may contribute to future comparisons of other cohorts of adolescents that are not only using the implant, but also with earlier diagnosis and intervention.

\section{CONCLUSION}

When analyzing the period elapsed between diagnosis and intervention, the data demonstrated that there was significant impact on the development of oral communication, in such a way that the faster the intervention, the better the results. It was also evident that the earlier the use of the cochlear implant, the higher the hearing age and the greater the rehabilitation period, as well as the better the scores in the procedures that evaluated auditory and verbal development.

\section{REFERENCES}

1. Delgado-Pinheiro EMC, Antonio FL, Berti LC. Perfil audiológico e habilidades auditivas em crianças e adolescentes com perda auditiva. Rev Est Ling. 2010;39(1):10-20.

2. Oliveira LN, Goulart BNG, Chiari BM. Distúrbios de linguagem associados à surdez. J Hum. Growth Dev. 2013;23(1):41-5.

3. BRASIL. Portaria GM/MS no -1.278 , de 20 de outubro de 1999. Aprova critérios de indicação e contra indicação de implante coclear. Ministério da Saúde. 1999. Disponível em: http://bvsms.saude.gov.br/ bvs/saudelegis/gm/1999/prt1278_20_10_1999.html

4. BRASIL. Decreto № 7.612 , de 17 de novembro de 2011. Institui o Plano Nacional dos Direitos da Pessoa com Deficiência - Plano Viver sem Limite. Planalto. 2011. Disponível em: http://www.planalto. gov.br/ccivil_03/_Ato2011-2014/2011/Decreto/ D7612.html.

5. BRASIL. Portaria no $21 / \mathrm{SCTIE} / \mathrm{MS}$, de 7 de maio de 2013. Inclui o Procedimento de Sistema de Frequência Modulada Pessoal (FM) na Tabela de Procedimentos, Medicamentos, Órteses, Próteses e Materiais Especiais (OPM) do Sistema Único de Saúde. Ministério da Saúde. 2013. Disponível em: http://bvsms.saude.gov.br/bvs/saudelegis/ gm/2013/prt1274_25_06_2013.html.

6. BRASIL. Ministério da Saúde. Portaria GM/MS no 2.776, de 18 de dezembro de 2014. Brasilia, 2014. Disponivel em: http://bvsms.saude.gov.br/bvs/ saudelegis/gm/2014/prt2776_18_12_2014.html. Acesso em: 22/04/2015.

7. Pereira PKS, Martins AS, Vieira MR, Azevedo MF. Programa de triagem auditiva neonatal: associação entre perda auditiva e fatores de risco. Pró-Fono $\mathrm{R}$ Atual Cient. 2007;19(3):267-78.

8. Hilú MRPB, Zeigelboim BS. The knowledge and valorization of neonatal auditory screening and the early intervention of hearing loss. Rev. CEFAC. 2007;9(4):563-70.

9. Bevilacqua MC, Alvarenga KF, Costa OA, Moret AL. The universal newborn hearing screening in Brazil: from identification to intervention. Int $\mathrm{J}$ Pediatr otorhinolaryngol. 2010;74(5):510-5.

10. Downs MP, Yoshinaga-Itano C. The efficacy of early identification and intervention for children with hearing impairment. Pediatr Clin North Am. 1999;46(1):79-87.

11. Marciano E, Laria C, Malesci R, Iadicicco P, Landolfi E, Niri C et al. Newborn hearing screening in the Campania region (Italy): early language and perceptual outcomes of infants with permanent hearing loss. Acta Otorhinolaryngol Ital. 2013;33(6-):414-7.

12. Giuntini G, Forli F, Nicastro R, Ciabotti A, Bruschini L, Berrettini S. Early care in children with permanent hearing impairment. Acta Otorhinolaryngol Ital. 2016;36(1):51-9.

13. Fulcher AN, Purcell A, Baker E, Munro N. Factors influencing speech and language outcomes of children with early identified severe/profound hearing loss: Clinician identified facilitators and barriers. Int $J$ Speech Lang Pathol. 2015;17(3):325-33.

14. Fulcher A, Purcell AA, Baker E, Munro N. Listen up: Children with early identified hearing loss achieve age-appropriate speech/language outcomes by 3 years-of-age. Int J Pediatric Otorhinolaryngol. 2012;76(12):1785-94.

15. World Health Organization. Childhood hearing loss: strategies for prevention and care. [cited $2016 \mathrm{Nov}$ 15]. Available from: http://apps.who.int/iris/bitstrea m/10665/204632/1/9789241510325_eng.pdf.

16. Pinto MM, Raimundo JC, Samelli AG, Carvalho ACM, Matas CG, Ferrari GMS et al. Idade no 
diagnóstico e no início da intervenção de crianças deficientes auditivas em um serviço público de saúde auditiva brasileiro. Arq Int Otorrinolaringol. 2012;16(1):44-9.

17. Holt RF, Svirsky MA. An exploratory look at pediatric cochlear implantation: is earliest always best? Ear Hear. 2008;29(4):492-511.

18. Baudonck N, Dhooge I, D'haeseleer E, Van Lierde K. A comparison of the consonant production between Dutch children using cochlear implants and children using hearing aids. Int $\mathrm{J}$ Pediatr Otorhinolaryngol. 2010;74(4):416-21.

19. Bevilacqua MC, Formigoni GMP. O desenvolvimento das habilidades auditivas. In: Bevilacqua MC, Moret ALM. Deficiência auditiva: conversando com familiares e profissionais de saúde. São José dos Campos: Pulso Editorial; 2005. p. 179-202.

20. Connor CM, Craig HK, Raudenbush SW, Heavner $\mathrm{K}$, Zwolan TA. The age at which young deaf children receive cochlear implants and their vocabulary and speech-production growth: is there an added value for early implantation? Ear Hear. 2006;27(6):628-44.

21. Angelo TCS, Bevilacqua MC, Moret ALM. Percepção da fala em deficientes auditivos pré-linguais usuários de implante coclear. Pró-Fono R Atual Cient. 2010;22(3):3.

22. Novaes BCAC, Versolatto-Cavanaugh MC, Figueiredo RSL, Mendes BCA. Fatores determinantes no desenvolvimento de habilidades comunicativas em crianças com deficiência auditiva. J Soc Bras Fonoaudiol. 2012;24(4):335-41.

23. Ferreira MIDC, Sant'Anna LM. Conhecimento de usuários de aparelhos auditivos sobre 0 processo de adaptação. Arq Int Otorrinolaringol. 2008;12(3):384-92.

24. Couto MIV, Carvalho ACM. Fatores que influenciam na participação dos pais de crianças usuárias de implante coclear na (re)habilitação oral: revisão sistemática. CoDAS. 2013;25(1):84-91.

25. Estabrooks W. Auditory-Verbal Therapy: For parents and professionals. Washington, DC: Alexander Graham Bell Association for the Deaf; 1994.

26. Castiquini EAT. Escala de integração auditiva significativa: procedimento adaptado para a avaliação da percepção da fala [dissertação]. São Paulo(SP): Pontifícia Universidade Católica; 1998. Adaptado de: Zimmerman-Phillips S; Osberger MJ; Robbins AM. Infant-Toddler: Meaningful Auditory
Integration Scale (IT-MAIS). Sylmar, Advanced Bionics Corporation, 1997.

27. Castiquini EAT, Bevilacqua MC. Escala de integração auditiva significativa: procedimento adaptado para a avaliação da percepção da fala. Rev Soc Bras Fonoaudiol. 2000;4(6):51-60.

28. Nascimento LT. Uma proposta de avaliação da linguagem oral [Monografia] Bauru (SP): Hospital de Pesquisa e Reabilitação de Lesões lábioPalatais - USP; 1997.

29. Eisenberg LS, Widen JE, Yoshinaga-Itano C, Norton S, Thal D, Niparko JK et al. Current state of knowledge: implications for developmental research key Issues. Ear Hear. 2007;28(6):773-7.

30. Desajardin JL, Ambrose SE, Martinez AS, Eisenberg LS. Relationships between speech perception abilities and spoken language skills in young children with hearing loss. Int $\mathrm{J}$ Audiol. 2009;48(5):248-59.

31. Kral A, Sharma A. Developmental neuroplasticity after cochlear implantation. Trends Neurosci. 2012;35(2):111-22.

32. Dettman SJ, Dowell RC, Choo D, Arnott W, Abrahams Y, Davis A et al. Longterm communication outcomes for children receiving cochlear implants younger than 12 months: a multicenter study. Otology \& Neurotology. 2016;37(2):82-95.

33. Mo B, Harris S, Rasmussen K. Social hearing measured with the Performance Inventory for Profound and Severe Loss: a comparison between adult multichannel cochlear implant patients and users of acoustical hearing aids. Int $\mathrm{J}$ Audiol. 2004;43(10):572-8.

34. Geers AE. Techniques for assessing auditory speech perception and lip-reading enhancement in young deaf children. Volta Rev. 1994;96(5):85-96.

35. Baumgartner WD, Pok SM, Egelierler B, Franz P, Gstoettner W, Hamzavi J. The role of age in pediatric cochlear implantation. Int $\mathrm{J}$ Pediatr Otorhinolaryngol. 2002;62(3):223-8.

36. Ritcher B, Eisseke S, Laszig R, Lohle E. Receptive and expressive language skills of 106 children with a minimumof 2 year's experience in hearing with a cochlear implant. Int. J. Pediatr. Otorhinolaryngol. Amsterdam. 2002;2(64):111-25. 